\title{
Milling and air classification of two different types of peas - effects on the distribution of antinutritional factors
}

\author{
A. F. B. VAN DER POEL 1 , H. L. M. AARTS 1 \& W. STOLP2 \\ 1 Dept. of Animal Nutrition, Agricultural University Wageningen, Haagsteeg 4, 6708 PM \\ Wageningen, Netherlands \\ 2 Dept. of Food Science, Agricultural University Wageningen, Bomenweg 2, 6703 HD \\ Wageningen, Netherlands
}

Received 25 May 1989; accepted 18 August 1989

\begin{abstract}
The effect of milling and subsequent air classification of three cultivars of peas (Pisum sati$v u m$ L.) on the distribution of trypsin inhibitors, lectins and tannins was studied. Two different milling procedures and two different classifier settings were investigated. Cut points were calculated from particle size distribution curves of the coarse and fine fractions. Noticeably, proteinaceous antinutritional factors segregate into the fine fractions, the actual resulting levels being dependent on both the type of milling and the settings of the classifier.
\end{abstract}

Keywords: milling, air classification, fractionation, legumes, peas, antinutritional factors

\section{Introduction}

Peas (Pisum sativum L.) contain several antinutritional factors (ANF). For example they contain protein-type factors (trypsin inhibitors and lectins) and polyphenols (tannins). These factors may interfere with digestion when ingested by e.g. monogastric animals, depending on pea cultivar and f.i. feeding level. Some of these ANF can be inactivated by adequate heat treatments employed in processing procedures for several feedstuffs used in livestock feeding. Processing, based on the separation into fractions with high and low levels of ANF may be an alternative for the removal of at least some of the activity of ANF.

Dry milling of grain legumes and subsequent separation may be used to produce fractions with a different potential for use in feed and food manufacturing. Based on the different sizes and density differential between discrete protein bodies and starch granulas, air classification can be used to fractionate the legume flours into their main constituents (Vose et al., 1976).

Yield and composition of air-classified pea fractions have been studied by 
Reichert (1982) and the distribution of antinutritional factors after air classification of peas with regard to proteinaceous and other ANF have been studied by Elkowicz \& Sosulski (1982). However, different cultivars of pea may contain different levels of ANF. In addition, the fractionation of peas may be affected by the chosen classifier settings, like f.i. the used cut point. Therefore, the effect of varying the cut point on the separation of protein and antinutritional factors from two types of pea flour was examined.

\section{Materials and methods}

Whole pea flours were prepared from a smooth pea cultivar (Finale) and from two cultivars of wrinkled pea (cv. C306 and an unspecified high trypsin inhibitor containing cultivar, referred to as Cap. HTI. Milling was carried out using a Pallman mill (at $5000 \mathrm{rpm}$ ) or an Alpine $160 \mathrm{Z}$ pinn mill (at $11000 \mathrm{rpm}$ ). Air classification was carried out on a Alpine A 100 MZR classifier.

The different cut points $(10 \mu \mathrm{m}$ and $20 \mu \mathrm{m})$ were adjusted by varying the values of air flow rate and classifier speed. The values chosen were derived from preliminary studies with limestone.

The actual cut points were confirmed by particle size measurements with a Malvern 3300 P Particle Sizer using the definition of Wright et al. (1984). In this definition, cut point is defined as the particle size at which the yield (by weight) of undersize particles in the coarse fraction is equalled by the yield of oversize particles in the fine fraction.

Peas were subjected to treatment by the mill and the classifier, resulting in a protein-rich fraction (PI) and a starch-rich fraction (SI). The starch-rich fraction was remilled and air classification of this flour resulted in a protein-rich fraction (PII) and final starch-rich fraction (SII). The weight of the fractions was recorded and the level of antinutritional factors was analysed in flours and the fractions PI, PII en SII.

Trypsin inhibitor levels (as TIA) and the level of lectins (haemagglutinating activity, HA) were determined according to methods reported previously (van der Poel \& Huisman, 1988). Tannins were analysed with the method of Folin-Denis (Swain \& Hillis, 1981).

\section{Results and discussion}

In Fig. 1 the distribution of particles is shown after one and two passes through the Pallmann mill. Approximately $70 \%$ of the particles have diameters less than $35 \mu \mathrm{m}$. Remilling showed only little effect on particle size distribution of Finale. Wright et al. (1984), however, showed that the efficiency depends on the type of milling. In Fig. 2, an example of particle size analysis is given for the PI, PII and SII fractions of C306. This figure illustrates the typical particle size distribution for the fine and coarse fractions and thus clearly indicates the effect of air classification on the separation of particles. A lower cut point (results not illustrated) will result in finer particles in the fine fractions. 


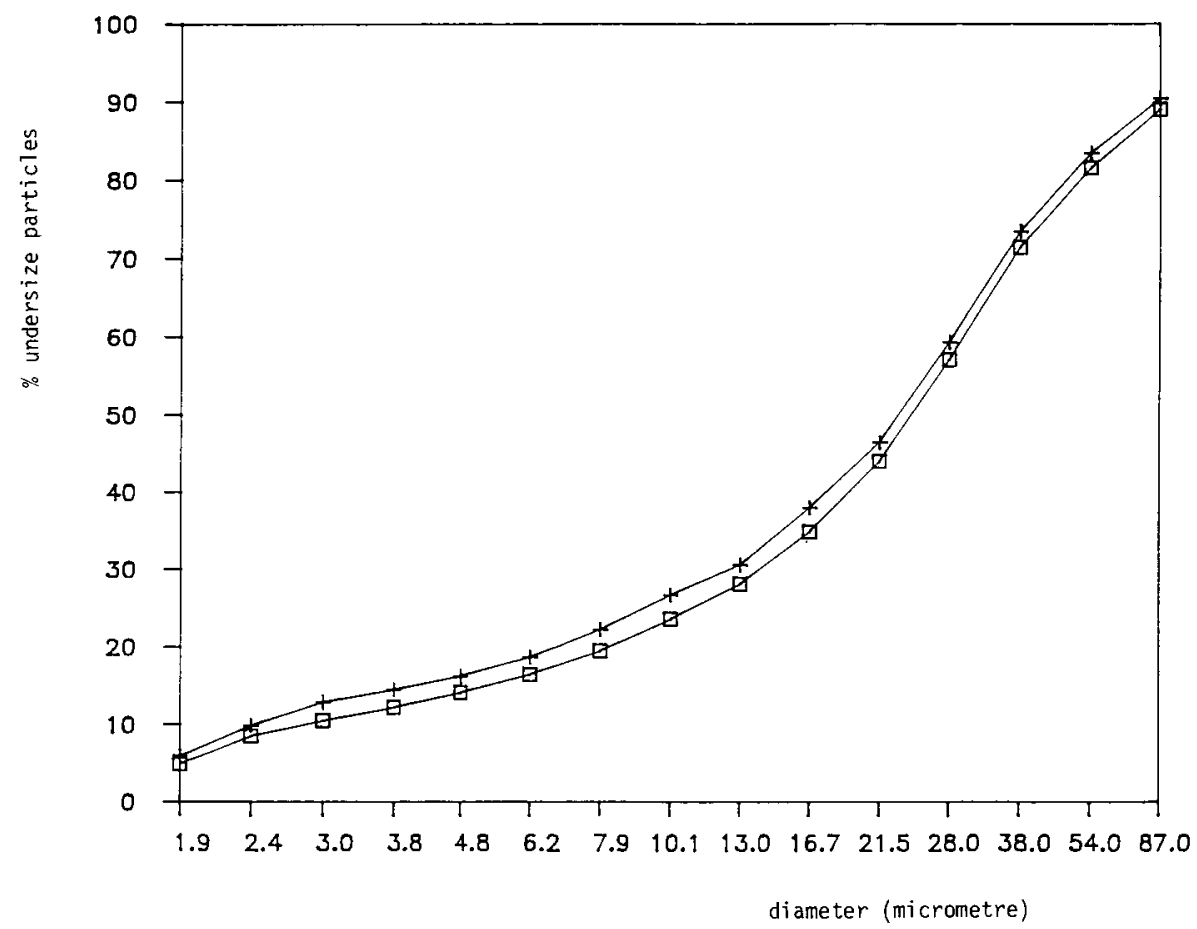

Fig. 1. Particle size distribution ( $\%$ undersize particles) of pea flour (cv. Finale) after one ( $\square$ ) and two $(+)$ passes through the mill.

Table 1. Yield (Yld, \%), dry matter content (DM, \%) and protein content (CP, \% DM) of flour and fine and coarse fractions after air classification with different cut points of pea flours of different cultivars milled with a Pallmann or pin mill.

\begin{tabular}{|c|c|c|c|c|c|c|c|}
\hline \multirow[t]{2}{*}{ Flour } & \multicolumn{6}{|c|}{ Air-classified fractions } & \\
\hline & PI & & PII & & & SII & \\
\hline $\begin{array}{ll}\text { DM } & \text { CP } \\
(\%) & (\%)\end{array}$ & $\begin{array}{ll}\text { Yld } & \text { DM } \\
(\%) & (\%)\end{array}$ & $\begin{array}{l}\text { CP } \\
(\%)\end{array}$ & $\begin{array}{l}\text { Yld } \\
(\%)\end{array}$ & $\begin{array}{l}\mathrm{DM} \\
(\%)\end{array}$ & $\begin{array}{l}C P \\
(\%)\end{array}$ & $\begin{array}{l}\text { Yld } \\
(\%)\end{array}$ & $\begin{array}{l}\text { DM } \\
(\%)\end{array}$ \\
\hline
\end{tabular}

Pin mill

$\begin{array}{lrlrlllllllll}\text { Finale }(10 \mu \mathrm{m}) & 86.7 & 25.6 & 6.0 & 90.4 & 65.0 & 2.8 & 90.8 & 61.6 & 91.2 & 87.5 & 21.6 & 22 \\ \text { Finale }(20 \mu \mathrm{m}) & 86.7 & 25.6 & 12.9 & 89.8 & 62.4 & 6.3 & 90.3 & 57.1 & 80.8 & 87.3 & 17.9 & 45 \\ \text { C306 }(20 \mu \mathrm{m}) & 86.5 & 24.3 & 15.7 & 90.0 & 55.9 & 5.2 & 90.4 & 53.4 & 79.1 & 87.3 & 17.0 & 44\end{array}$

Pallmann mill

$\begin{array}{lllllllllllll}\mathrm{C} 306(20 \mu \mathrm{m}) & 88.6 & 23.8 & 19.8 & 91.6 & 55.4 & 7.2 & 91.7 & 52.1 & 73.0 & 89.9 & 15.8 & 58\end{array}$

$\begin{array}{lllllllllllll}\text { Cap.HTI }(20 \mu \mathrm{m}) & 88.2 & 25.3 & 19.4 & 90.5 & 55.7 & 7.3 & 90.7 & 53.4 & 73.3 & 88.8 & 14.8 & 62\end{array}$

${ }^{1} \mathrm{Rec}=$ protein recovery $=($ total protein in fractions $\mathrm{Pl}+\mathrm{PII}) /($ total protein in flour $)$ 


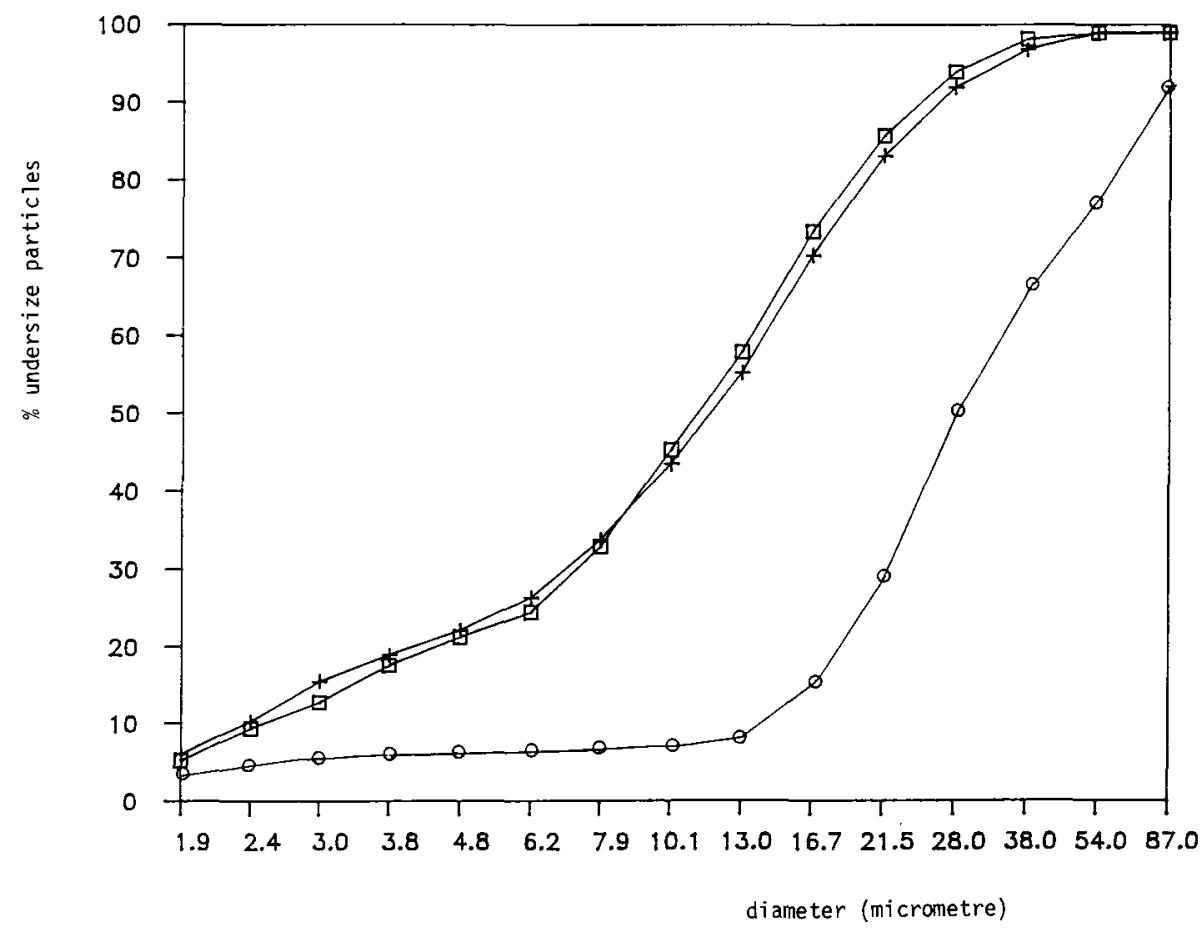

Fig. 2. Particle size distribution ( $\%$ undersize particles) of fine and coarse fractions obtained by air classification of pea flour (C306; cut point $20 \mu \mathrm{m}$; $\square$ PI, + PII, O SII).

Actual cut points, determined by particle size measurements of three batches of peas, were $12.3 \mu \mathrm{m} \pm 1.5$ and $18.0 \mu \mathrm{m} \pm 1.7$, whereas the theoretical cut points were $10 \mu \mathrm{m}$ and $20 \mu \mathrm{m}$, respectively.

In Table 1, data on the yield of the various fractions after air classification are shown. Lower yields of the fine fractions are obtained at lower cut points. The recovery of protein is defined as the total amount of protein in PI + PII divided by the total amount of protein in the flour. After milling with the pin mill and air classification with cut points of $10 \mu \mathrm{m}$ and $20 \mu \mathrm{m}$, the protein recovery of Finale is $22 \%$ and $45 \%$, respectively. This shows the marked effect of classifying conditions on the concentration of protein in the fine fractions. For C306, yields of the fine fractions ( $20 \mu \mathrm{m}$ cut point) are higher when the Pallmann mill is used for milling. Moreover, total protein recovery is increased to $58 \%$ as compared to $44 \%$ when the pin mill is used. Yields and protein content of Cap.HTI are comparable to those of C306.

Levels of trypsin inhibitor activity (TIA), lectins (measured as haemagglutinating activity, HA) and tannins were determined in samples of flours and air-classified fractions (Table 2). Following air classification, a clear distribution of the proteinaceous (TI and lectins) ANF between fine and coarse fractions in all pea cultivars 
Table 2. Distribution of trypsin inhibitors ${ }^{1}$, lectins ${ }^{2}$ and tannins $(\%)$ in pea flours and fractions after air classification.

\begin{tabular}{|c|c|c|c|c|c|c|c|c|c|c|c|c|}
\hline & \multicolumn{4}{|c|}{ Trypsin inhibitor } & \multicolumn{4}{|c|}{ Lectin } & \multicolumn{4}{|c|}{ Tannin } \\
\hline & \multirow[t]{2}{*}{ Flour } & \multicolumn{3}{|c|}{ Fractions } & \multirow[t]{2}{*}{ Flour } & \multicolumn{3}{|c|}{ Fractions } & \multirow[t]{2}{*}{ Flour } & \multicolumn{3}{|c|}{ Fractions } \\
\hline & & PI & PII & SII & & PI & PII & SII & & PI & PII & SII \\
\hline \multicolumn{13}{|l|}{ Pin Mill } \\
\hline Finale $(10 \mu \mathrm{m})$ & 1.07 & 3.54 & 2.84 & 0.90 & 10 & 50 & 40 & 16 & 0.41 & 0.67 & 0.70 & 0.33 \\
\hline Finale $(20 \mu \mathrm{m})$ & 1.07 & 3.43 & 3.70 & 1.39 & 10 & 40 & 40 & 16 & 0.41 & 0.70 & 0.70 & 0.30 \\
\hline $\mathrm{C} 306(20 \mu \mathrm{m})$ & 2.89 & 6.05 & 5.73 & 3.80 & 16 & 40 & 40 & 10 & 0.76 & 0.74 & 0.71 & 0.66 \\
\hline \multicolumn{13}{|l|}{ Pallmann mill } \\
\hline $\mathrm{C} 306(20 \mu \mathrm{m})$ & 2.53 & 15.19 & 6.16 & 1.78 & 16 & 50 & 50 & 10 & 0.69 & 0.76 & 0.77 & 0.63 \\
\hline Cap.HTI $(20 \mu \mathrm{m})$ & 5.55 & 22.70 & 8.05 & 2.75 & 16 & 32 & 32 & 10 & 0.65 & 0.69 & 0.72 & 0.60 \\
\hline
\end{tabular}

1 Weight fraction inhibited trypsin ( $\mathrm{mg} \mathrm{g}-1)$.

2 Haemagglutination activity $\left(\mathrm{g}^{-1}\right)$.

is obtained. For TI's and lectins a relative enrichment in the fine fractions is found. This is consistent with the proteinaceous nature of these ANF and has also been demonstrated for other legumes (Elkowicz \& Sosulski, 1982). However, ANF are still present in the coarse fraction after air classification. The levels in these fractions are close to the levels of the original flour when the pin mill is used. This does not agree with the results of Elkowicz \& Sosulski (1982). The total recovery of f.i. TIA in PI + PII + SII in some cases exceed $100 \%$. This may be attributed to the sensitivity of the TIA assay for the relative low levels found in peas. When the Pallmann mill is used the levels of TI in the coarse fraction derived from C 306 are substantially lower. Tannins, non-protein components, were found to separate in both the fine and coarse fraction. The absolute level of tannins in the initial pea flours, however, is relatively low. Their contribution to observed negative effects when feeding peas to animals has still to be investigated.

The results of the present studies confirm the findings of previous research (see Sosulski et al., 1987) that air classification is suitable to obtain pea protein concentrates. The protein content of the fine air classified fraction is negatively related to the yield of this fraction (Wright et al., 1984). Moreover, the protein-type antinutritional factors are concentrated in the fine fractions at levels of three- up to fourfold as compared to the original flour. The pea protein concentrate (PI + PII fraction) thus contains a high level of protein as well as high levels of ANF. Also, in the coarse fraction, ANF activity is still present. Utilization of these concentrates for livestock feeding, therefore, depends on the relative contribution of trypsin inhibitors, lectins and perhaps tannins to the overall effects observed with animals on such diets. These effects may vary with the differences of the gastro-intestinal tract from several animal species. Huisman \& van der Poel (1989) have found that piglets experienced negative effects from peas in contrary to chickens and rats. 


\section{References}

Elkowicz, K. \& F. W. Sosulski, 1982. Antinutritive factors in eleven legumes and their air-classified protein and starch fractions. Journal of Food Science 47: 1301-1304.

Huisman, J. \& A. F. B. van der Poel, 1989. Comparison of effects of antinutritional factors (ANFs) in different animal species. In: J. Huisman, A. F. B. van der Poel, I. E. Liener (Eds) Recent advances of research in antinutritional factors in legume seeds, p. 317-327, PUDOC, Wageningen, Netherlands.

Poel, A. F. B. van der \& J. Huisman, 1988. Effect of steam treatment of a dry bean (Phaseolus vulgaris L.) with extreme high lectin content on ileal digestibility in pigs. Proceeding of the IVth International Seminar on Digestive Physiology in the Pig, June 1988, Jablonna, Poland.

Reichert, R. D., 1982. Air classification of peas (Pisum sativum) varying widely in protein content. Journal of Food Science 47: 1263-1267.

Sosulski, F. W., A.F. Walker, P. Fedec \& R. T. Tyler, 1987. Comparison of air classifiers for separation of protein and starch in pin-milled legume flours. Lebensmittel-Wissenschaft und Technologie 20: $221-225$.

Swain, T. \& W. E. Hillis, 1981. Phenolic constituents of Prunus domestica. I. Quantitative analysis of phenolic constituents. Journal of the Science of Food and Agriculture 10: 63-68.

Vose, J. R., M. J. Basterrechea, P. A. J. Gorin, A. J. Finlayson \& C. G. Youngs, 1976. Air classification of field peas and horsebean flours: chemical studies of starch and protein fractions. Cereal Chemistry 53: $928-936$.

Wright, D. J., M.R. Bumstead, D. T. Coxon, H. S. Ellis, M. S. Dupont \& H. W.-S. Chan, 1984. Air classification of pea flour-analytical studies. Journal of the Science of Food and Agriculture 35: $531-542$.

This synopsis is based on a report entitled 'Droge fractionering in erwten-effect op de verdeling van antinutritionele factoren' by $A$. F. B. van der Poel, H. L. M. Aarts, S. W. Stolp. Dept. of Ainimal Nutrition/Dept. of Food Science, Wageningen Agricultural University, Wageningen, 1989, 49 pp., 16 figs., 21 tables, 18 refs., 3 apendices, in Dutch, English summary. Available as paper copy (order R097f 12 including portage) at: NARD, clo Pudoc, P.O. Box 4, 6700 AA Wageningen (telex 45015 bluwg $n l)$. 